\title{
Perception of Environmental Impacts of Wind Farms in Agricultural Areas of Northeast Brazil
}

\author{
Manoel Fortunato Sobrinho Junior ${ }^{1}$, Maria Carolina Ramirez Hernandez ${ }^{2}$, Sthenia Santos Albano Amora ${ }^{3}$ \\ and Elis Regina Costa de Morais $4, *$ (D)
}

1 Maintenance and Physical Facilities Division, Federal University of the Semiarid-UFERSA, Mossoro 59625-900, Brazil; manoel.junior@ufersa.edu.br

2 Environment, Technology and Society Program, Agricultural Sciences Center, Federal University of the Semiarid-UFERSA, Mossoro 59625-900, Brazil; maria.ramirez@alunos.ufersa.edu.br

3 Agricultural Sciences Center, Federal University of the Semiarid-UFERSA, Mossoro 59625-900, Brazil; sthenia@ufersa.edu.br

4 Engineering Center, Federal University of the Semiarid-UFERSA, Mossoro 59625-900, Brazil

* Correspondence: elisregina@ufersa.edu.br

Citation: Sobrinho Junior, M.F.; Ramirez Hernandez, M.C.;

Albano Amora, S.S.;

Costa de Morais, E.R. Perception of Environmental Impacts of Wind Farms in Agricultural Areas of Northeast Brazil. Energies 2022, 15, 101. https://doi.org/10.3390/ en15010101

Academic Editor: Adrian Ilinca

Received: 11 August 2021 Accepted: 9 November 2021 Published: 23 December 2021

Publisher's Note: MDPI stays neutral with regard to jurisdictional claims in published maps and institutional affiliations.

Copyright: (c) 2021 by the authors. Licensee MDPI, Basel, Switzerland. This article is an open access article distributed under the terms and conditions of the Creative Commons Attribution (CC BY) license (https:// creativecommons.org/licenses/by/ $4.0 /)$.

\begin{abstract}
In recent years, wind power in Brazil has emerged as an alternative to diversify the country's energy mix and minimize the emission of pollutants derived from fossil fuels. The state of Rio Grande do Norte, in the Brazilian Northeast, has considerable potential for the generation of wind energy due to the occurrence of strong winds in many areas along the coast and in the interior of the state, in places with higher altitudes. However, wind energy, despite being considered clean and renewable, can cause environmental impacts in those places. Thus, the present study analyzed the perception of environmental impacts caused by the installation of wind farms in the agricultural areas of Northeast Brazil. The study was carried out in the municipality of Serra do Mel, in the western region of the state of Rio Grande do Norte, based on a survey of local farmers. The study concluded that farmers live without major problems and without apparent conflicts with wind farms but have little knowledge about the environmental impacts. In the perception of most farmers, there are few negative environmental impacts, and those that exist are barely noticed or still do not cause damage to most farmers in the region.
\end{abstract}

Keywords: impacts; local communities; wind energy; wind park; sustainability

\section{Introduction}

The demand for alternative renewable energy production is increasing around the world, especially with the official commitment of various government authorities to reduce atmospheric emissions of greenhouse gases and other pollutants by replacing fossil fuels with renewable sources. Among the renewable sources that have received incentives for expansion around the world, we highlight wind energy [1].

In Brazil, the state of Rio Grande do Norte (RN) has the largest installed capacity of wind power plants in commercial operation in Brazil, with the capacity to generate $4.3 \mathrm{GW}$ of energy [2]. The region is characterized by constant winds with an average speed between 5 and $9 \mathrm{~ms}^{-1}$ and favorable topography that combine to make this state the largest producer in Brazil, reverting from an energy importer status to becoming an energy supplier, and being responsible for generation of approximately 38.95\% of the entire wind generation in the Northeast and $32.72 \%$ of the Brazilian wind generation [2], this shows the relevance of the wind sector in the state.

The coastal territories, which often present land tenure uncertainties [3], were, by public policies, legitimized and standardized for renewable energy projects that, by their nature, occupy large tracts of land to produce electricity [4]. Currently, there is a process of interiorization, advancing towards the semiarid region, especially in areas dominated by 
mountains, tablelands and plateaus [5], with preference for flat rural areas, and without vegetation, obstacles or significant buildings, since they offer the most stable wind flow [6].

Causes of opposition to wind farms in coastal territories in $\mathrm{RN}$, were reported by Dantas et al. [7] and Gorayeb et al. [8], point out that wind farms may represent an imposition of people's attachment to landscapes. Community residents may feel marginalized because they do not participate in planning decisions or because they receive few benefits, and people may complain about health effects. On the other hand, high social adherence to wind energy is observed where the payment of royalties and leases to owners occurs where the turbines are installed, and where the positive economic impacts $[9,10]$ are visible, that is, there is a good acceptance of renewable energy at the national level, while there are several cases of opposition and rejection of projects in certain places [11].

It is easy to imagine that the prospects for expansion of wind energy in agricultural areas and the possible conflicts with the local community tend to intensify, but, as reported by do Juarez et al. [12], there is optimism in the analysis of engineers who argue that wind energy is compatible with rural activities and that it increases the income of the rural population. Thus, understanding the local population dynamics and their perceptions concerning the benefits and damages resulting from these ventures enables investors and public entities, responsible for project planning, to improve their management and licensing models in order to reduce potential environmental and social constraints originating from wind farm implementation [7].

Considering that the impacts generated by the implantation of wind farms in agricultural areas in the northeast region of Brazil is still an underexplored topic, it is necessary to analyze the perception of local residents in relation to the environmental changes that have taken place and the contributions to the community. This study presents an analysis, through the perception of residents in the agricultural areas of Serra do Mel-RN, which basically had their economy and customs linked to subsistence agriculture, of the environmental impacts caused by the installation and operation of wind farms. Initially, documentary research raising public domain narratives enabled assessments of the different perceptions of those involved in the process, then field research was carried out with the local population, through the application of questionnaires, in order to determine the perception of the community on the environmental impacts arising from the very existence of wind farms, before and after their implementation.

\section{Material and Methods}

\subsection{Study Area}

This study was carried out in the municipality of Serra do Mel $\left(05^{\circ} 10^{\prime} 12.0^{\prime \prime}\right.$ south latitude and $37^{\circ} 01^{\prime} 44.4^{\prime \prime}$ west longitude), Rio Grande do Norte (Figure 1 ). The municipality is located in a transition area between the coast and hinterland, with an average altitude of $185 \mathrm{~m}$, receiving trade winds from the Atlantic Ocean. The climate is predominantly semiarid, characterized by low and irregular rainfall. The vegetation is mainly typical of the Caatinga biome (shrubland), and the topography is mainly flat to gently undulating [13].

The municipality of Serra do Mel was born from a resettlement project conceived in 1970, started in 1972, but only concluded in 1982. In a short time, it became an important agricultural area of the state, mainly through the cultivation of cashew (Anacardium occidentale), both for processing of fruits into juice for the domestic market and nuts for the export market. In 1988, Serra do Mel achieved its political autonomy, becoming a municipality, the only one to have its origin from a landless workers' settlement area in the state [13].

The population according to the most recent census is 10,287 inhabitants, of which 7589 live in the rural area, covering $620,241 \mathrm{~km}^{2}$ [13]. This area is subdivided into 23 villages, with 22 rural villages (community production villages) and one central village (each village is named after a Brazilian state) (Figure 1). Rural villages are made up of 59 plots, usually with 50 hectares (ha) each. In these plots, 15 ha is typically devoted to cultivation of cashew trees (Anacardium occidentale), 10 ha for temporary crops and 25 ha reserved for native forest [14]. 


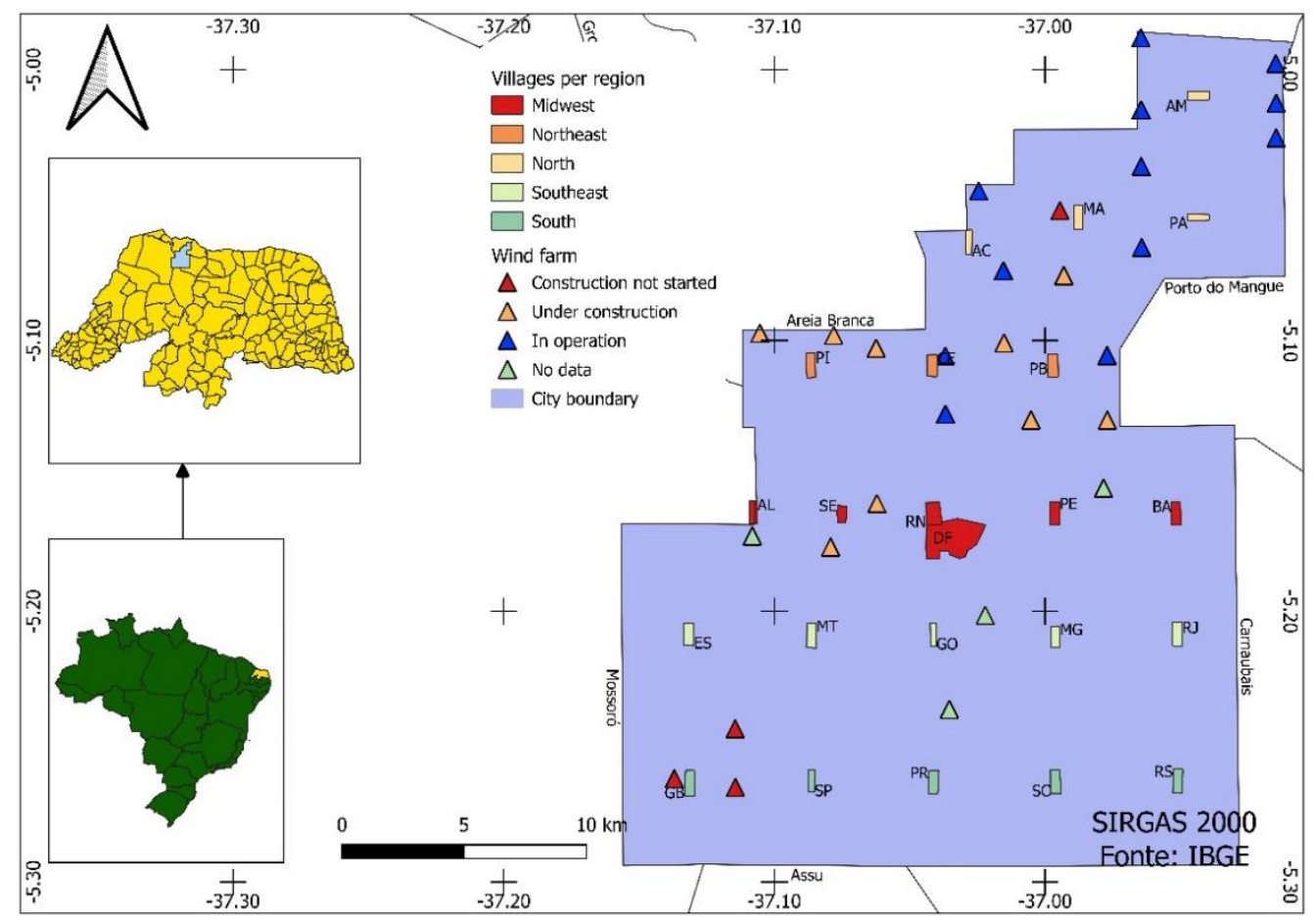

Figure 1. Map of location and division of towns and regions in the municipality of Serra do Mel. Lagend of the villages: Acre (AC), Alagoas (AL), Amazonas (AM), Bahia (BA), Brasília (DF, urban area), Ceará (CE), Espirito Santo (ES), Goiás (GO), Guanabara (GB), Maranhão (MA), Mato Grosso (MT), Minas Gerais (MG), Pará (PA), Paraíba (PB), Paraná (PR), Pernambuco (PE), Piauí (PI), Rio de Janeiro (RJ), Rio Grande do Norte (RN), Rio Grande do Sul (RS), São Paulo (SP), Santa Catarina (SC) and Sergipe (SE).

The main economic activity of the municipality is the production and processing of cashew nuts, but since 2015 it has received investments in the area of wind energy. Growth in this sector has elevated Serra do Mel to the largest producer of wind energy in the state and the second in the country. Currently, there are twelve wind farms in operation, nine under construction and eight authorized with construction not started, with total power potential of $1176 \mathrm{MW}$ [2]. These wind power facilities are located in the villages of Amazonas, Pará, and Acre (all in the north region of the municipality).

\subsection{Classification of the Survey}

In view of the character of the formulated research problem, the study can be classified as descriptive, as its primary objective is to describe the characteristics of a given population or phenomenon, or to establish relationships between variables [15]. Regarding approach, it is qualitative, it seeks to understand a phenomenon based on information provided by the interviewed subjects. It is also case study, since it involves collecting and analyzing information about a certain group or community, with the objective of explaining, exploring, or describing current phenomena [15].

\subsection{Data Collection}

For data collection, we divided the municipality into five regions (according to the regional division of Brazil—South, Southeast, Midwest, Northeast, and North), as shown in Figure 1. In total, 220 interviews were carried out in the 22 rural villages. Among the interviewees are farmers who were or will benefit from the exploitation of wind farms, randomly selected, considering the characteristics of a stratified probability sample [16]. To ensure the representativeness conferred by the generic conditions of investigation and for the convenience of the interviewee, the participants' privacy was maintained. 
The interviews were held in the yard/residence of each farmer because the domestic environment gives the interviewee a sense of freedom to express ideas and experiences [17].

To define the sample population, the theory for finite samples [15] and the theoretical saturation criterion [18] were considered. The saturation criterion is an objective validation process in research that adopts methods, addresses themes, and collects information in sectors and areas where probabilistic treatment of the sample is impracticable or unnecessary [19], being used to determine when the researcher should finish the data collection process [20].

Data were collected from semi-structured interviews, where questions are combined in order to allow participants to talk and verbalize about their thoughts, trends and reflections about the phenomenon studied [21]. To define the questions, a study of the main environmental impacts generated by the installation of wind farms was carried out, as identified in the Environmental Impact Reports (RIMAs) available on the website of the Institute for Sustainable Development and the Environment of Rio Grande do Norte (IDEMA). The interview script was built with topics that addressed the perception of each interviewee of the environmental impacts generated by wind farms in relation to vegetation suppression, road opening, soil vibration, visual effects, electromagnetic interference, pollution noise, and risks of accidents with wildlife.

Previously, three pilot interviews were carried out in order to validate the script and adjust the questions to avoid dubious interpretations, doubts, and/or variety of answers, which could compromise the rigor of the method, obtaining of the data, and, subsequently, the reach of theoretical saturation. After the instrument was validated, data collection began, which took place from December 2019, to February 2020.

At the end of each interview, the collected data were analyzed to identify new and replicated answers to the same question. We adopted as a saturation point a minimum of six similar answers in the same village, and two more answers later. From there we used the saturation point to a confirmation. To verify the theoretical saturation [22], various processes were followed, including pre-analysis, material exploration, treatment of results, inference, and interpretation.

\subsection{Data Processing}

The data collected in the interviews were submitted to a systematization of responses and content analysis, followed by transfer to an electronic spreadsheet (Microsoft Excel), where the data were selected, categorized, and processed to allow qualitative analysis.

\section{Results and Discussion}

Regarding the knowledge of the negative environmental impacts generated by wind farms, the respondents in all regions had a low level of knowledge or were totally unaware of the subject (Figure 2a). However, some farmers cited suppression of native forests and cashew trees, a decrease in the production of cashew fruits and nuts due to the dust caused by the increase in vehicle traffic near the orchards, the low amount paid as royalties and indemnities for land use, absence of social projects, and problems with infrastructure due to the excessive use of roads. The general perception was of no possibility of risks to the health and safety of the population caused by the wind projects, now or in the future.

In two other municipalities, Areia Branca and Galinhos, also in Rio Grande do Norte, residents perceived negative impacts on the environment due to the installation of wind farms. In the first one with emphasis on the suppression of native vegetation and the driving away/mortality of fauna [4], and in the second, construction of access roads, violation of an archaeological site, and removal of sand dunes, with disposal of the sand in the Aruatá River, aggravating silting [7]. However, a survey conducted in Cyprus found that the vast majority of respondents did not believe wind farms had a negative impact on the local environment [23].

In Serra do Mel, some farmers had no knowledge the negative impacts of wind farms, mentioning there was no information in this respect supplied by companies. However, for 
farmers in the north region, where a wind farm is already in operation, information had been provided through meetings, lectures, and newsletters organized/prepared by the management company. In the community of Ponta do Mel, municipality of Areia Branca, $\mathrm{RN}, 55.71 \%$ of the residents said they were informed, but of these $30.76 \%$ stated that the main positive benefit was the generation of temporary jobs [24].

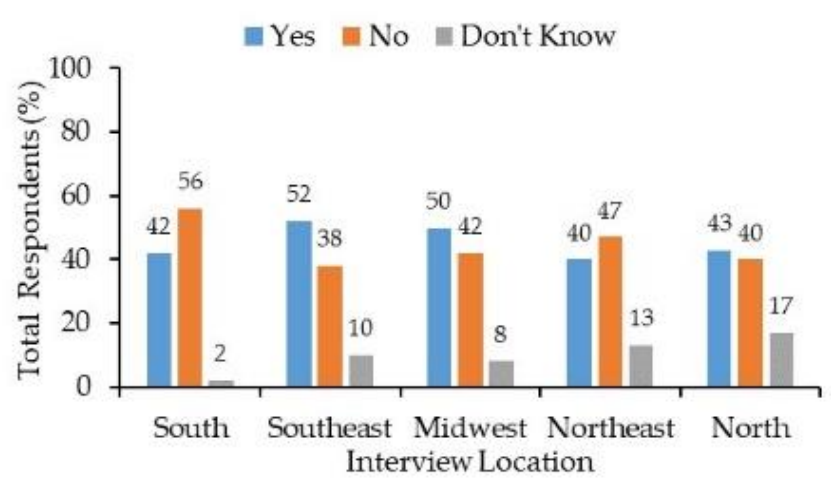

(a)

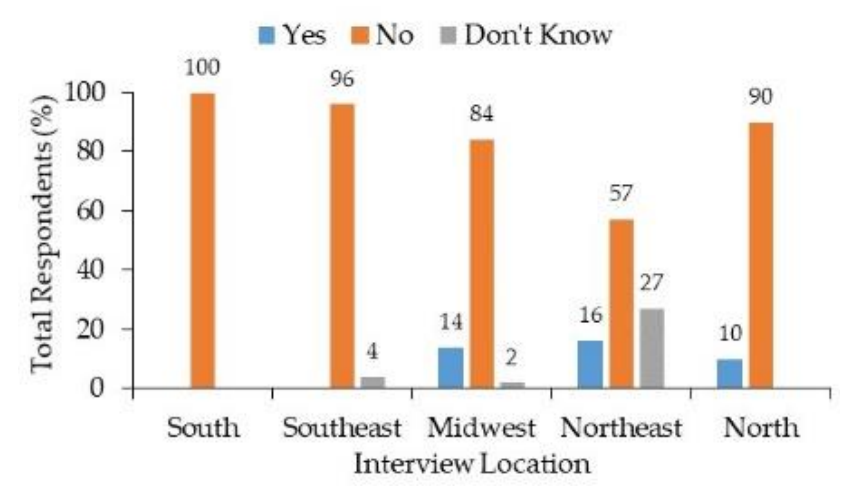

(b)

Figure 2. Perception about the existence of negative impacts (a), perception about monitoring the implementation of wind farms by an environmental agency (b), according to the total number of interviewees by region. Source: elaborated by the author.

Similar results were also found in Cyprus, where $32 \%$ of communities close to wind farms were inadequately informed [25], as well as in Austria, where a study by Scherhaufer et al. [25] concluded that the management companies of wind farms should inform the community and the general public in more timely fashion, and that the information should include the number of turbines, expected location, investment and local benefits, environmental and human impacts, and future opportunities to participate in the decision-making process, for example, to express an opinion in the environmental impact assessment). Meetings, communications, special information days, on-the-spot inspections, and face-to-face contacts were mentioned as appropriate methods of information sharing.

Thus, it is possible to verify a general pattern of failure of communication between companies and local residents, who only perceive reality during the installation and/or operational phase of the projects. In a survey conducted in the region of Weatherford, USA, more than $75 \%$ of the participants responded they had some knowledge of wind energy and that their knowledge had increased since the wind farm became operational [26].

Regarding the monitoring of the environmental agency that issued the construction and operation licenses, $85 \%$ of the respondents did not know of any monitoring or inspection of the wind farms, but 16,14 , and $10 \%$ of the respondents in the northeast, mid-west and north regions of the municipality, respectively (see Figure $2 b$ ), stated there was monitoring by the environmental agency, but were unable to state its name or the frequency. A study carried out in municipalities in the Brazilian state of Paraíba found there were limitations to the sustainable development of wind farms, mainly due to lack of training in local communities, lack of specific legislation, and absence of inspection by the competent government agencies [27].

When asked about the use and occupation of the municipality's land by wind farms, $40 \%$ of the farmers in the north and northeast regions (Figure $3 \mathrm{a}$ ), where facilities are either operating or under construction, mentioned the perception, besides the use of the internal areas of the lots, of the opening of new roads and construction of transmission lines running through the lots and/or villages. In Portugal, the improvement of access roads to the wind farm was seen as a generally positive result by the local community [28], while in Galinhos, RN, 75\% of respondents said the opening of roads had led to a greater flow of cars, but the population was divided as to the benefits or damages of this change in the way of life [7]. 


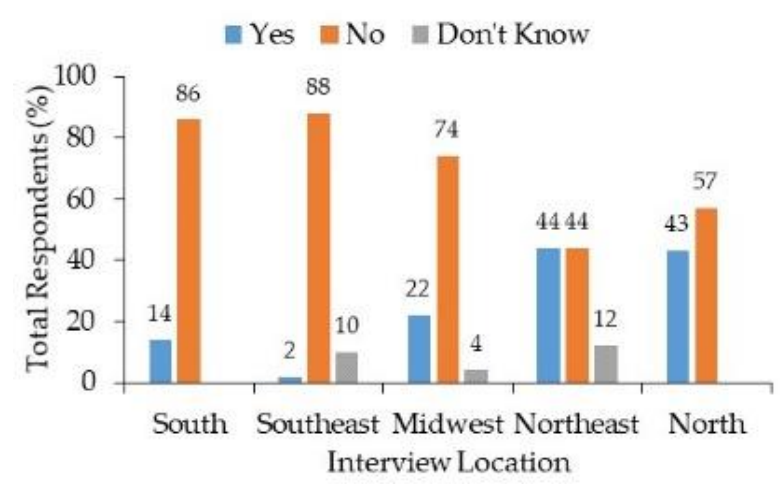

(a)

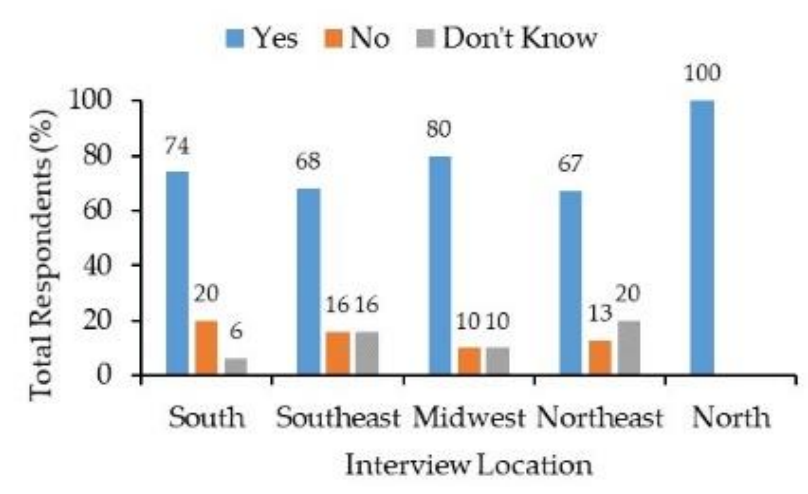

(b)

Figure 3. Perception of use and occupation of the plot area by towers and roads (a) and perception about the suppression of vegetation in the lot and villages (b) according to the total number of interviewees by region. Source: elaborated by the author.

According to Mustafa and Al-Mahadin [29], in many cases, new roads are built so that wind turbines can be transported and installed in rural areas. However, in other cases it is necessary to use existing public roads to transport large wind turbine components. According to Loureiro et al. [30], deforestation to build access routes to wind turbines requires suppression of environments with unique fauna and flora and causes destruction of natural habitats.

In Serra do Mel, so far, vegetation suppression has occurred in the north, northeast and midwest regions, where wind power facilities are operating, or in the construction process. However, in all regions there was perception of the suppression of vegetation, as shown in Figure $3 \mathrm{~b}$. The respondents stated that the loss of their land area for installation of towers varied between 8 and 10 ha and represented 16 to $20 \%$ of the total area. This area includes places where cashew trees or native forest previously existed, and that transmission lines and substations had been established in some villages. Some respondents also stated that it is only known how much will be removed from each lot at the time of construction, since contracts are signed without defining which lots and how much of each lot will be required.

As mentioned by Nazir et al. [31], the removal of native or agricultural vegetation for the construction of wind farms can contribute to undesirable climate changes, such as irregular rainfall patterns, leading to soil erosion. In the community of Zumbi, in the municipality of Rio do Fogo, $\mathrm{RN}$, the residents realized it was necessary to remove native vegetation, but did express concern over this loss [32].

There were no reports of significant losses of area and production by farmers, corroborating the findings of Lucena and Lucena [33], that wind farms occupy little physical space, allowing owners to continue normal farming and stock-breeding activities. Studying wind farms in Tunisia, Kardous et al. [34], found that more than $90 \%$ of the property occupied by wind towers had the same original use, often agriculture, and that areas with native vegetation can continue to thrive. However, the intense growth of the wind sector can reduce the availability of agricultural areas and cause conflicts due to differences in land use and occupation [35].

Regarding the erosive processes resulting from the installation of wind farms, more than $50 \%$ of farmers, in all regions, confirmed they did not notice any problems (Figure $4 a$ ). However, it should be considered that during the construction of a wind farm, excavation of foundations and construction of roads by heavy machinery can cause soil compaction and affect the local bio-system and erosion processes [29,30], which is intensified by plant suppression. The respondents mentioned that the absence of erosion may be related to the municipality's soil being sandy with good drainage. 


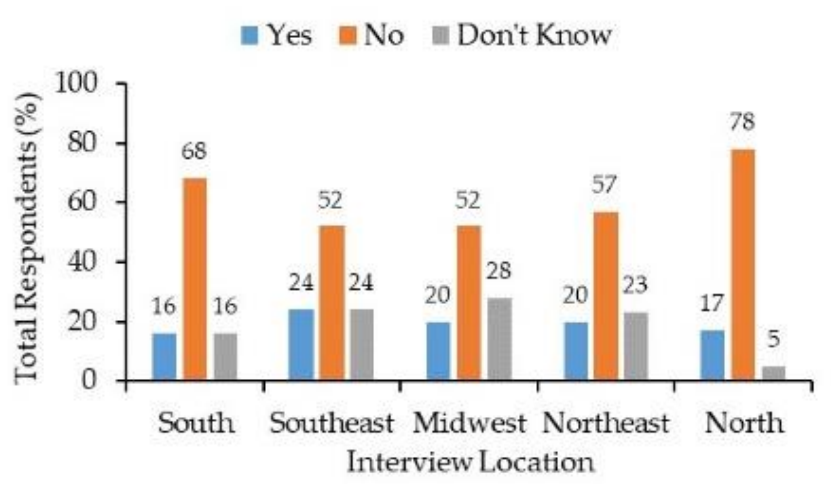

(a)

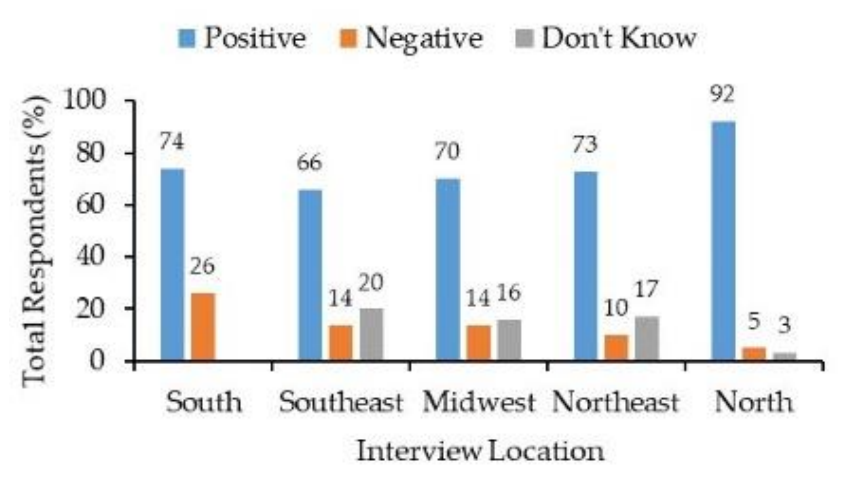

(b)

Figure 4. Perception in relation to environmental instability (a), perception of changes in the landscape (b), according to the total number of interviewees by region. Source: elaborated by the author.

Although the vibrations transmitted by wind turbines are too insignificant to be recognized by affecting human beings [9], farmers in the Ceará village, in the Northeast region, noticed the occurrence of vibrations on the ground. We must consider that this is the closest village to a park wind turbine under construction, therefore these vibrations may happen due to geotechnical and hydrogeological studies, soil compaction and movement of cars and heavy machinery, mainly affecting old buildings weakened by time or those built with construction materials of inferior quality [36]. The tower is designed to withstand operating vibrations throughout the life of the wind turbine as the rotor and blade passage frequencies can cause the forces acting on the tower to increase, which can lead to a level dangerous in structural integrity [37].

The alteration of the landscape is considered one of the main environmental impacts that the construction of wind farms have on their surroundings. This affects the land surface, drainage systems and vegetation, causing changes in environmental dynamics that can reduce environmental quality and biodiversity [29]. The reaction caused by a wind farm is highly subjective, some view wind towers positively, as a symbol of clean energy, while others react negatively to the new landscape [38].

In relation to this impact, the visual effect of the towers was considered to be a positive point by $75 \%$ of the farmers, as shown in Figure $4 \mathrm{~b}$. They mentioned that the wind farms did not cause visual disturbance, despite the replacement of green areas formerly containing cashew trees with towers, aerogenerators, wiring, transmission lines and new roads.

In Galinhos, RN, $15 \%$ of the population stated they were disturbed by the presence of wind towers, alleging visual intrusion with the potential to harm tourism and trade [7]. However, in Cyprus, $72 \%$ of the population expressed the opposite opinion [25]. In Portugal and the United Kingdom $70 \%$ of people do not have a negative opinion about wind turbines $[39,40]$, but another study argued that the installation point should be chosen so as to minimize the visual impact and the appearance of shadows and reflections [41].

Generally, the smaller the number of wind turbines and the simpler the layout, the easier it is to create a balanced and consistent image [8], since the negative visual impacts of these installations on the landscape are generally linked to excessive density of wind turbines more than by the individual effect of each one. Thus, in general terms, a reduction in the number of turbines, despite an increase in height, should translate into a decrease in the impact of future wind farms $[42,43]$.

Lucena and Lucena [33] claimed that electromagnetic interference due to the presence of wind farms close to telecommunication transmitters and receivers can generate distortion, although the magnetic field of a wind turbine is extremely weak. This interference also depends on technical specifications, mainly the material used to manufacture the blades. However, modern blades are made of synthetic materials that have a minimal impact on the transmission of electromagnetic radiation, and possible interference from the electrical system can be easily eliminated with proper insulation and good maintenance [41]. 
In Serra do Mel, the assertion of no noticeable interference with communication equipment or other electronic devices was, on average, over $68 \%$, but $29 \%$ of respondents said they did not know (Figure 5a). This can be attributed to the rural location of the villages, where these services are precarious and the interferences, which can be small, will hardly be noticed.

- Yes $=$ No $\quad$ Don't Know

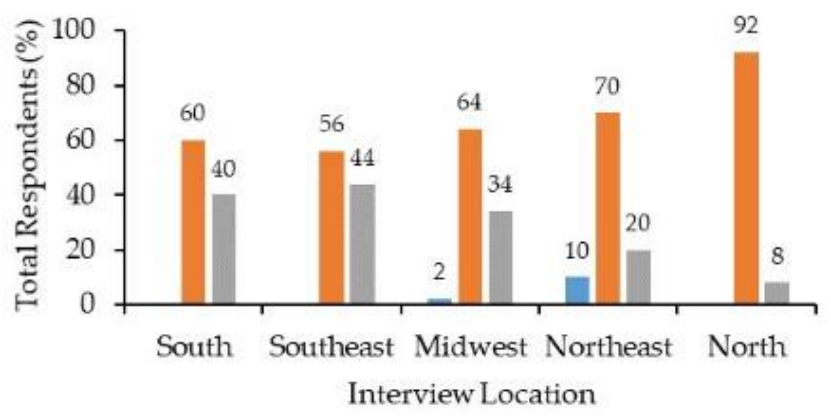

(a)

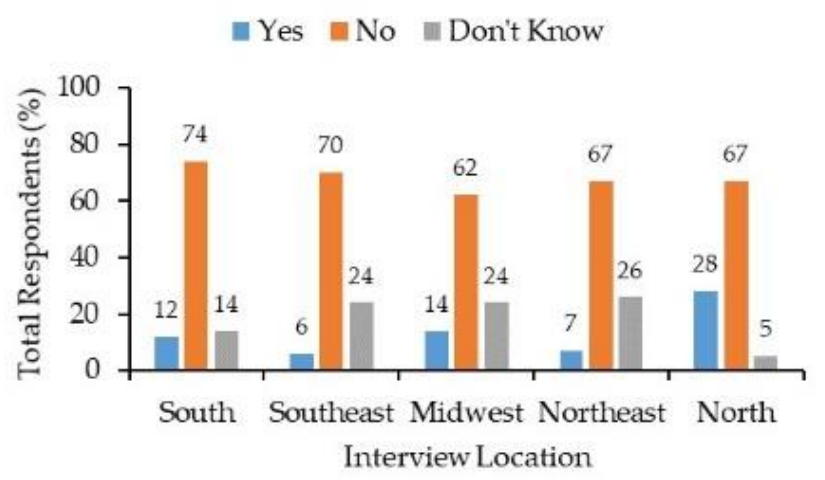

(b)

Figure 5. Perception in relation to electromagnetic interference (a), and perception regarding the risks of accidents with Avifauna (b), according to the total number of interviewees by region. Source: elaborated by the author.

When asked about noise pollution, only farmers in the north region reported this problem, but mentioned they had become used to it or that the noise was insignificant, being more intense at night. In this region, the towers are located 1 to $2 \mathrm{~km}$ from villages. Jami and Walsh [42], when evaluating the perception and annoyance related to noise from wind turbines in populated areas of Poland observed no significant association between noise level (or distance) and health and well-being, but symptoms of stress were positively associated with annoyances related to wind turbine noise or traffic intensity on the roads, and even at a distance of $1 \mathrm{~km}$, the noise of wind turbines can be perceived as highly irritating when outdoors by $43 \%$ and $2 \%$ of people with a negative and positive attitude towards wind turbines, respectively. In Cyprus, $68 \%$ of the population did not think that the wind farm caused noise pollution [29].

Some countries have established a minimum distance between wind farms and housing or follow recommendations from health institutions, which vary from 300 to $1500 \mathrm{~m}$, or have been defined based on the diameter of the rotor and height of the tower [4]. The noise levels of current wind turbines are in the range of 98 to $104 \mathrm{~dB}$ at a wind speed of $8 \mathrm{~ms}^{-1}$, which results in exposure to about 33 to $40 \mathrm{~dB}$ for a person $500 \mathrm{~m}$ away [36].

In the Ceará village, located in the northeast region, the wind farm is under construction and the towers will be approximately $500 \mathrm{~m}$ away from the village, so farmers expressed doubts about the negative effects of noise pollution, fearing that with the construction of new facilities this problem can become worse and cause damage to the health of the community. According to Custódio [43], $400 \mathrm{~m}$ is a safe distance from a wind turbine, since the noise is less than $40 \mathrm{~dB}$. Magari et al. [44] concluded there is little or no evidence that the audible and subaudible noises emitted by the turbines have adverse psychological impacts on the population, with the exception of self-reported sleep disturbances, and that the disturbance caused by these noises is a phenomenon that depends on various factors, including individual sensitivity.

Regarding the risk of accidents with birds, $68 \%$ and $19 \%$ of the respondents reported not having noticed or did not know about, respectively, an increase in bird mortality after the installation of wind farms, but $28 \%$ of the respondents in the north region stated they observed dead birds around the bases of wind towers (Figure 5b), an observation that corroborates the results in Galinhos, RN [20]. 
In studies conducted of wind farms in the USA, Canada, and Spain, it was found that bird mortality rates varied from 0.02 to 7.36 birds per turbine/year. The authors concluded that bird deaths vary among species, and birds of prey are more susceptible than other species, but annual avian mortality resulting from wind farms is lower than that of other energy industries, such as nuclear and fossil fuel plants or other structures in the USA. However, the small annual avian mortality from wind farms cannot be ignored, especially of wind farms with several hundred or even thousands of turbines. Due to this complexity, there is no simple technique that can be widely used for mitigation strategies. The best mitigation alternative may include a mixture of more than one measure, adjusted to the specificities of each site, wind farm, and target bird species [45].

Some farmers in the municipality of Serra do Mel mentioned little or no attraction of birds due to the absence of surface water bodies, but they did not know if the companies carry out studies necessary to mitigate this problem. The National Center for Research and Conservation of Wild Birds (CEMAVE) recommends the use of flashing lights and tubular structures in the towers, automatic or manual shutdown of the turbines in case of approaching bird flocks, and avoiding installation in natural landscapes, among other specific regional recommendations [46].

According to a study by Łopucki and Mróz [47], the emission of noise, electromagnetic effects, vibration, and the movement of blades can generate disturbances in the environment and possibly make the surrounding areas less suitable as wildlife habitats by impairing vocal communication of the animals or the ability of animals to hear predators [48].

Adeyeye et al. [49] stated that a set of wind turbines causes risks of mortality and disturbance of birds, since noises and turbulent drafts produced by the operation of wind turbines can scare birds away and reduce their territories. Birds and bats are considered the main victims due to collisions with rotating blades. Another risk to birds is the trauma caused by the sudden change in pressure generated by the movement of the blades (barotrauma), causing hemorrhages and leading to death [50].

Regarding disturbance to wild terrestrial fauna, farmers were divided. Some claimed it happened, and cited armadillos as the most affected animals. Others claimed that these animals only moved to another part of the land during the construction process. Still, other farmers were unable to name which wild animals were affected. In Rio do Fogo, $\mathrm{RN}$, the scavenging of local fauna was mentioned by people who noticed an increase in wild animals, for example snakes and spiders, or who had contact with local hunters who reported the disappearance of some species [32].

Respondents in the villages where the wind towers were under construction reported that beekeeping activity was being affected by the noise of machinery and traffic intensity, in addition to the escape of bees, possibly due to the decrease in bee flora and increase in noise pollution. This fact is one of the biggest concerns of farmers, since bees are the main pollinators of cashew trees, so any disturbance of bees can cause reduced production and income; the cultivation of cashew and processing of nuts are the main economic activities of Serra do Mel. In Portugal, some residents expressed concerns about beehives, but did not know if the wind farms are harmful. However, this potential problem can be a source of social rejection of wind power by some farmers in the region [51].

\section{Conclusions}

Regarding environmental impacts, the respondents had little knowledge about the negative impacts caused by the installation of wind farms. They were generally optimistic about the lack of impacts and did not suffer, or did not mention, these environmental problems. We also found there was little effort by the companies to provide information, as well as little information from environmental agencies on the impacts caused by wind farms. The farmers mainly reported problems only during construction. Another point that drew attention was the lack of monitoring or inspection by environmental agencies at the federal, state or municipal level. 
However, it was possible to observe that the main environmental impacts resulting from the implementation of wind farms to date have caused little harm to economic and social activities, property values and the lives of farmers. The most cited were vegetation suppression, loss of productive area and dust caused by vehicle traffic.

Few plots and farmers had been affected by plant suppression for the installation of wind turbines or access routes. However, the growth of wind energy in the municipality of Serra de Mel has caused concern relating to the reduction in cashew production, whether due to the loss of planted area, farmers' lack of interest in maintaining this activity, or the environmental impacts, such as deforestation, dust caused by vehicles disturbing pollinating fauna, and local climate change.

Visual interference was considered to be positive; most farmers considered the project to be beautiful. Erosion, ground vibrations, changes in the climate, electromagnetic interference, and noise pollution were not widely reported or judged to have negligible impacts. There has, so far, been little impact on the region's fauna and flora, except for local beekeeping.

Author Contributions: All authors have contributed equally to this study. All authors have read and agreed to the published version of the manuscript.

Funding: This study was financed in part by the Coordenação de Aperfeiçoamento de Pessoal de Nível Superior-Brazil (CAPES) Finance Code 001.

Institutional Review Board Statement: The study was conducted in accordance with the guidelines of the Declaration of Helsinki and approved by the Research Ethics Committee of the State University of Rio Grande do Norte, protocol code 33339420.5.0000.5294, approved on 2 September 2020.

Informed Consent Statement: Respondents consented to participate in the survey. But as reported in the methodology, they were not identified. The perception of the community and not of each respondent was obtained.

Data Availability Statement: Not applicable.

Conflicts of Interest: The authors declare no conflict of interest.

\section{References}

1. Aso, R.; Cheung, W.M. Towards greener horizontal-axis wind turbines: Analysis of carbon emissions, energy and costs at the early design stage. J. Clean. Prod. 2015, 86, 263-274. [CrossRef]

2. Aneel-National Electricity Agency. Information System ANEEL (SIGA); Brazil's Generation Capacity; 2020. Available online: http://www.aneel.gov.br/siga (accessed on 4 February 2020).

3. Brannstrom, C.; Gorayeb, A.; De Souza, W.F.; Leite, N.S.; Chaves, L.O.; Guimarães, R.; Gê, D.R.F. Perspectivas geográficas nas transformações do litoral brasileiro pela energia eólica. R. Bras. Geogr. 2018, 63, 3-28. [CrossRef]

4. Junior, A.O.P.; Soares, J.B.; Oliveira, R.G.; Queiroz, R.P. Indicadores Energéticos Para o Desenvolvimento Sustentável: Uma Análise a Partir do Plano Nacional de Energia; COPEL: Curitiba, Brazil, 2014; p. 303.

5. Traldi, M. The socioeconomic and territorial impacts resulting from the implementation and operation of wind farms in the Brazilian semiarid region. Electron. J. Geogr. Soc. Sci. Univ. Barc. New Writ. 2018, 22, 589. [CrossRef]

6. Cîrstea, S. Socio-Economic Impact of Wind Turbines Implementation. Annals of the "Constantin Brâncuşi" University of Târgu Jiu, Economy Series, Issue 6/2015 Academica Brâncuşi" Publisher. Available online: https:/ / econpapers.repec.org/article/ cbujrnlec/y_3a2015_3av_3a6_3ap_3a145-151.htm (accessed on 5 February 2020).

7. Dantas, E.J.D.A.; Rosa, L.P.; Da Silva, N.F.; Pereira, M.G. Wind Power on the Brazilian Northeast Coast, from the Whiff of Hope to Turbulent Convergence: The Case of the Galinhos Wind Farms. Sustainability 2019, 11, 3802. [CrossRef]

8. Gorayeb, A.; Brannstrom, C.; Serrano, A.M.; Manent, M.B. Toward participatory management of renewable energy resources (wind-farm) in northeastern Brazil. Mercator 2016, 15, 101-115. [CrossRef]

9. Brannstrom, C.; Jepson, W.; Persons, N. Social Perspectives on Wind-Power Development in West Texas. Ann. Assoc. Am. Geogr. 2011, 101, 839-851. [CrossRef]

10. Slattery, M.C.; Johnson, B.L.; Swofford, J.A.; Pasqualetti, M.J. The predominance of economic development in the support for large-scale wind farms in the U.S. Great Plains. Renew. Sustain. Energy Rev. 2012, 16, 3690-3701. [CrossRef]

11. Bell, D.; Gray, T.; Haggett, C.; Swaffield, J. Re-visiting the 'social gap': Public opinion and relations of power in the local politics of wind energy. Environ. Politics 2013, 22, 115-135. [CrossRef]

12. Juárez, A.A.; Araújo, A.M.; Rohatgi, J.S.; Filho, O.D.Q.D.O. Development of the wind power in Brazil; political, social, and technical issues. Renew. Sustain. Energy Rev. 2014, 39, 828-834. [CrossRef] 
13. IBGE-Brazilian Institute of Geography and Statistics. Cities. 2017. Available online: https://cidades.ibge.gov.br/brasil/rn/serrado-mel/panorama (accessed on 3 February 2020).

14. Rocha, A.P.B. Oil Activity and Territorial Dynamics in Rio Grande do Norte: An Analysis of the Municipalities of Alto do Rodrigues, Guamaré and Mossoró. Ph.D. Thesis, UFPE, Recife, Brazil, 2013; p. 279. Available online: https://repositorio.ufpe.br/ bitstream/123456789/10362/1/aristotelina_tese.pdf (accessed on 2 February 2020).

15. Gil, A.C. How to Design Research Projects, 5th ed.; Atlas: São Paulo, Brazil, 2008.

16. Richardson, R.J. Pesquisa Social: Métodos e Técnicas, 3rd ed.; Atlas: São Paulo, Brazil, 1999.

17. Duarte, R. Qualitative research: Reflections on fieldwork. Res. Noteb. 2002, 115, 139-154. [CrossRef]

18. Fontanella, B.J.B.; Ricas, J.; Turato, E.R. Saturation sampling in qualitative health research: Theoretical contributions. Public Health Noteb. 2008, 24, 17-27. [CrossRef]

19. Nascimento, L.D.C.N.; de Souza, T.V.; Oliveira, I.C.D.S.; de Moraes, J.R.M.M.; de Aguiar, R.C.B.; da Silva, L.F. Theoretical saturation in qualitative research: An experience report in interview with schoolchildren. Rev. Bras. Enferm. 2018, 71, 228-233. [CrossRef] [PubMed]

20. Falqueto, J.M.Z.; Hoffmann, V.E.; Farias, J.S. Theoretical Saturation in Qualitative Research: Report of an Experience of Application under study in the Administration Field. Rev. Ciências Adm. 2018, 20, 40-53. [CrossRef]

21. Virgillito, S.B. Pesquisa de Marketing: Uma Abordagem Quantitativa e Qualitativa; Saraiva: São Paulo, Brazil, 2010.

22. Bardin, L. Análise de Conteúdo; Edição 70: Lisboa, Portugal, 2009.

23. Fokaides, P.A.; Miltiadous, I.-C.; Neophytou, M.K.-A.; Spyridou, L.-P. Promotion of wind energy in isolated energy systems: The case of the Orites wind farm. Clean Technol. Environ. Policy 2014, 16, 477-488. [CrossRef]

24. Ferreira, F.S.M.; Camacho, R.G.V.; De Carvalho, R.G. Perception of socio-environmental impacts of the implementation of wind farms in the community of Ponta do Mel, Areia Branca/RN. Geosul. Florianópolis 2019, 34, 262-279. [CrossRef]

25. Scherhaufer, P.; Höltinger, S.; Salak, B.; Schauppenlehner, T.; Schmidt, J. Patterns of acceptance and non-acceptance within energy landscapes: A case study on wind energy expansion in Austria. Energy Policy 2017, 109, 863-870. [CrossRef]

26. Greene, J.S.; Geisken, M. Socioeconomic impacts of wind farm development: A case study of Weatherford, Oklahoma. Energy Sustain. Soc. 2013, 3, 2. [CrossRef]

27. Barbosa, A.P.A.; Cândido, G.A. Municipal sustainability and wind projects: A comparative analysis of municipalities with investments in wind power generation in the Paraíba State. Soc. Nat. J. 2018, 30, 68-95. [CrossRef]

28. Ferreira, P.; Lima, F.; Ribeiro, F.; Vieira, F. A mixed-method approach for the assessment of local community perception towards wind farms. Sustain. Energy Technol. Assess. 2019, 33, 44-52. [CrossRef]

29. Mustafa, A.M.Y.; Al-Mahadin, A. Risk assessment of hazards due to the installation and maintenance of onshore Wind turbines. Adv. Sci. Eng. Technol. Int. Conf. (ASET) Abu Dhabi 2018, 1, 1-7. [CrossRef]

30. Loureiro, C.V.; Gorayeb, A.; Brannstrom, C. Deployment of wind energy and estimation of environmental losses in a sector of the west coast of Ceará, Brazil. Geosaberes 2015, 6, 24-38. Available online: http://www.geosaberes.ufc.br/geosaberes/article/view/ 361 (accessed on 20 April 2020).

31. Nazir, M.S.; Ali, N.; Bilal, M.; Iqbal, H.M.N. Potential environmental impacts of wind energy development: A global perspective. Curr. Opin. Environ. Sci. Health 2020, 13, 85-90. [CrossRef]

32. Nunes, A.C.P.; Carmelo, G.L.P.; Ataíde, G.C.; Silva, R.G. Environmental perception in proposing indicators for assessing environmental impacts of wind farms. Confins 2019, 41. [CrossRef]

33. Lucena, J.A.Y.; Lucena, K.A.A. Wind energy in Brazil: An overview and perspectives under the triple bottom line. Clean Energy 2019, 3, 69-84. [CrossRef]

34. Kardous, M.; Aloui, F.; Chaker, R. Main Environmental Impacts of Wind Projects: Case of Tunisia. Univers. J. Renew. Energy 2013, 1, 42-50. Available online: http:/ / www.papersciences.com/Kardous-Univ-J-Renew-Ener-Vol1-2013-4.pdf (accessed on 2 February 2020).

35. Premalatha, M.; Abbasi, T.; Abbasi, S.A. Wind energy: Increasing deployment, rising environmental concerns. Renew. Sustain. Energy Rev. 2014, 31, 270-288. [CrossRef]

36. Moura-Fé, M.M.; Pinheiro, M.V.A. Wind farms in the coastal zone of Ceará and the associated environmental impacts. Geonorte J. 2013, 9, 22-41. Available online: http:/ / www.periodicos.ufam.edu.br/revista-geonorte/article/view/1142 (accessed on 1 February 2020).

37. Olariu, C.P. Soil-Structure Interaction in the Case of a Wind Turbine; Buletinul Institutului Politechnic Din Lasi. Sectia Constructii, Arhitectura: Berlin, Germany, 2013; pp. 159-174.

38. Van Der Wall, E.C. Local impact of community renewable energy: A case study of an Orcadian community-led wind scheme. Energy Policy 2020, 138, 111193. [CrossRef]

39. Silva, L.; Delicado, A. Wind farms and rural tourism: A Portuguese case study of residents and visitors perceptions and attitudes. Morav. Geogr. Rep. 2017, 25, 248-256. [CrossRef]

40. Nazir, M.S.; Mahdi, A.J.; Bilal, M.; Sohail, H.M.; Ali, N.; Iqbal, H.M. Environmental impact and pollution-related challenges of renewable wind energy paradigm-A review. Sci. Total Environ. 2019, 683, 436-444. [CrossRef]

41. Pinto, L.I.C.; Martins, F.R.; Pereira, E.B. The Brazilian wind energy market, social and environmental impacts. Environ. Water J. 2017, 12, 1082-1099. [CrossRef] 
42. Pawlaczyk-Łuszczyńska, M.; Zaborowski, K.; Dudarewicz, A.; Zamojska-Daniszewska, M.; Waszkowska, M. Response to Noise Emitted by Wind Farms in People Living in Nearby Areas. Int. J. Environ. Res. Public Health 2018, 15, 1575. [CrossRef] [PubMed]

43. Custódio, R.S. Wind Energy for Electric Energy Production, 2nd ed.; Revised and Expanded; Synergia: Acta: Abeeólica: Rio de Janeiro, Brazil, 2013.

44. Magari, S.R.; Smith, C.E.; Schiff, M.; Rohr, A.C. Evaluation of community response to wind turbine-related noise in Western New York State. Noise Health 2014, 16, 228. [CrossRef] [PubMed]

45. Wang, S.; Wang, S.; Smith, P. Ecological impacts of Wind farms on birds: Questions, hypotheses, and research needs. Renew. Sustain. Energy Rev. 2015, 44, 599-607. [CrossRef]

46. Tolmasquim, M.T. Renewable Energy: Hydraulic, Biomass, Wind, Solar, Oceanic. Rio Janeiro EPE 2016, 1, 10.

47. Łopucki, R.; Mróz, I. An Assessment of non-volant terrestrial vertebrates response to wind farms-A study of small mammals. Environ. Monit. Assess. 2016, 188, 1-9. [CrossRef]

48. Helldin, J.O.; Jung, J.; Neumann, W.; Olsson, M.; Skarin, A.; Widemo, F. The Impacts of Wind Power on Terrestrial Mammals; A Synthesis-Report 6510; Swedish Environmental Protection Agency: Stockholm, Sweden, 2012. Available online: http:// naturvardsverket.se/Documents / publikationer6400/978-91-620-6510-2.pdf (accessed on 3 February 2020).

49. Adeyeye, K.; Ijumba, N.; Colton, J. Exploring the environmental and economic impacts of wind energy: A cost-benefit perspective. Int. J. Sustain. Dev. World Ecol. 2020, 27, 718-731. [CrossRef]

50. Mcnew, L.B.; Gregory Sàbiamente, S.M.; Sandercock, B.K. Effects of Wind Energy Development on Nesting Ecology of Greater Prairie-Chickens in Fragmented Grasslands. Conserv. Biol. 2014, 28, 1089-1099. [CrossRef]

51. Delicado, A.; Figueiredo, E.; Silva, L. Community perceptions of renewable energies in Portugal: Impacts on environment, landscape and local development. Energy Res. Soc. Sci. 2016, 11, 84-93. [CrossRef] 